\title{
PSYCHOLOGICAL VIEWS IN JURISPRUDENTIAL THEORIES *
}

\author{
ROBERT S. REDMOUNT †
}

\begin{abstract}
Jurisprudential inquiry proceeds upon certain assumptions about the nature of man. Psychological theorizing is an enterprise directed toward the critical examination of assumptions such as these, and the formulation of hypotheses about human conduct. Yet despite the patent interdependence of these disciplines, there has been little effort made to correlate them. In this Article, Mr. Redmonnt, who is both a psychologist and a lazyer, examines the psychological theories of certain jurisprudents, and the theories of law of certain psychologists. Building upon this discussion, the anthor offers a set of systematized hypotheses which center about the psychological dependency of the individual on his enviromment. Mr. Redmount's prior writings have dealt with the application of psychological principles to the more practical courtroom aspects of law.
\end{abstract}

It seems strange, at least to a psychologically trained person, that theories relating to law give so little consideration to psychological man. It is as though man were substantially an incident of law or that his adaptation to conceptions of law is to be taken as a matter of course. Perhaps there is some implicit notion concerning the nature of man that is built into the theorizing given to law, or perhaps there is the feeling that man cannot be understood except as he is part of some larger social process.

It is, in fact, more reassuring to take man for granted because only in that way can one most effectively exercise the gifts of thought. And legal theorists are thinking persons wedded to thought as the mainspring of human action, regarding it as the legitimate source of experience, motivation and control. There is much to be said for this point of view, and also much that is left out.

Theories of man in existing theories of law are hard to come by. They occur infrequently-at least, they are not articulated very muchand, where they exist, they are not developed.

* The author is greatly in the debt of Professor William Morison of the University of Sydney and last year Senior Fellow and Lecturer at the Yale University School of Law. It was he who suggested that the author develop this Article beyond mere personal formulation into an analysis and critique of notable psychological views in jurisprudence. It was his gracious but incisive criticisms, and those of Dr. Jaques Kaswan, late of Yale University and presently of the Psychology Department of the University of California at Los Angeles, that delivered the probity of the writing. An appointment as Research Associate under a National Institute of Health grant to the Yale Law School made possible the preparation and presentation of this Article.

$\dagger$ Member, Connecticut Bar. A.B., 1943, M.S., 1947, Pennsylvania State University; Ph.D., 1949, New York University; LL.B., 1957, Yale University. 


\section{KarL OLIVECRONa}

The fullest psychological treatment given in law is to be found in the jurisprudence of the "Scandinavian realists," and most particularly in the work of Professor Olivecrona. ${ }^{1}$ Professor Olivecrona's psychological man is a creature driven by egoistic desire. He seeks primarily "self preservation, security, power and the like." 2 In fact, Olivecrona implies that man's essential motives- "drives" is perhaps a more accurate term-are even baser. They appear to be hostile and violent in character. ${ }^{3}$ It is, at bottom, this view of man, shared by Hobbes and later by Freud, that gives rise to the urgency and the utility of law. The principal rules of law curb baser desires through a prolonged educative process. The rules of law project into view ideas about behavior, "ideas of imaginary actions by people in imaginary situations . . . the actions [serving] as models for actual conduct when the corresponding situations arise in real life." 4 The ideas-sometimes they are said to be feelings-are the "binding force of the law"-the essential theme in Olivecrona's views.

The hypnotic effect of rules of law is traced back to an account of magical influence in the operation of Roman law, by reference to Hägerström's work on the Roman concept of Obligation. ${ }^{5}$ Our "imaginary" notions of rules of law are recognized as having influenced behavior at one time because of the practice of investing statements of duty and obligation with automatic properties for generating effects. The words invoked or contained magic, and expectations of fulfillment or penalty were thought to be invariably realized. More nearly toward the present, notions of rules of law are recognized to have meaning and effect because of the consequences that usually and logically follow from the understandings and the actions implied in declarative statements. ${ }^{6}$ Causation has traversed the range from ideas of magic to those more nearly related to logic. But, whatever the explanation, notions of rules of law are recognized to have regular meanings and effects in experience. There is, in fact, a long history of adaptive response to legal rules that has cumulatively resulted in a "habitual obedience to rules." 7

However, Professor Olivecrona makes out that it is not entirely habit and custom that are the sources of obedience to law. The imperative form of rules stresses the urgency that behavior take a peculiar form

1. Olivecrona, Law as fact (1939).

2. Id. at 169 .

3. Id. at 125 .

4. Id. at $29-30$.

5. Id. at 114 .

6. Id. at 115 .

7. Id. at 52-53. 
and direction. 8 And, to insure an attitude of obedience toward the law, or to prevent disobedience, the threat of force, administered by the state, acts as a secondary reinforcement.

Force operates through a dual process of suggestion and effect, operating sometimes in concert and sometimes independently of one another. Professor Olivecrona emphasizes that it is not just the awareness of specific applications of organized (state-controlled) force but the general subconscious awareness of the existence of organized force that impresses itself on the consciousness of man and exerts pressure toward lawful behavior. ${ }^{9}$

The influence of force can take place because of the suggestive and educative effects induced by fear of punishment. However, this is regarded as secondary or, at least, subconscious in the motivational processes of the typical human being. A pathological or unlawful desire opposed by a threat of punishment and an accompanying sense of fear, existing as a constant tension state for the individual, is regarded as "intolerable" and "disruptive" for most persons. Instead, we tend to exclude "thought of unlawful acts" from consciousness because we seek "peace of mind instinctively." 10 The awareness of force acts primarily or most immediately to reinforce "habits of obedience to rules" which serve to personal advantage in social relations. ${ }^{11}$ Rules of law concern not only the "don'ts" of human relations but also the "do's." Force according to the rules educates not only about wrong but also about right. ${ }^{12}$

If we make out Professor Olivecrona's psychological thesis correctly, his view of the human being is not unlike that of Freud. It is more diffuse in some respects and demonstrates a greater sociological bent in others. Clearly, law is a centripetal force for mankind for Olivecrona, while in Freud it is scarcely given formal notice.

Olivecrona, like Freud, postulates basal instincts, though he does not label them as such. Freud refers to instincts of sex and aggression ${ }^{13}$ and Olivecrona makes specific mention of "desires for selfpreservation, for security, for power and the like," ${ }^{14}$ more in the schismatic psychoanalytic tradition of Alfred Adler and the later "neo-

8. Id. at 31 .

9. Id. at $140-43$.

10. Id. at $147-48$.

11. See $i d$. at 144 .

12. See $i d$. at 169 .

13. See the elementary discussion of Freud's instinct hypotheses and their present status in BrenNer, AN Elementary TextBooK of Psychoanalysis 16-33 (Anchor ed. 1957). See also Hendrick, Facts and Theories of Psychoanalysis 91-140 (3d ed. 1958).

14. Olivecrona, op. cit. supra note 1 , at 169. 
Freudians," Karen Horney and Erich Fromm. It was Adler who premised man's behavior on his "longing for superiority," 15 and Horney who stressed man's effort to achieve a "feeling of greater security," 16 particularly neurotic man's, through "the quest for power, prestige and possession." 17 And it was Fromm who probed man's impotence and isolation in relation to the world, resulting in "mechanisms of escape" from his "freedom," sometimes by slavish adherence to and dependence upon custom or overpowering authority. ${ }^{18}$

Olivecrona proposes a view of consciousness as a dynamic process. A dualism or continuum is established between conscious thought and activity, and something-less-than-conscious. Something like Freud's fundamental schema of behavior, with the important delineation of an ained and vaunted "unconscious," seems implicitly assumed. ${ }^{19} \mathrm{Be}-$ havior tendency, in both Olivecrona and Freud, exists at minimally two levels or stages of experience. The tendencies that are more remote from external reality appear to be more primitive and unsocial, though subject to social influences. Those closer to reality, and to a state of conscious awareness-in Freud they are merely a different form of the same tendency-are commonly more adaptive and altruistic. It is they, most of all, or most immediately, that are influenced by the pressures arising from social experience.

The social experience that Olivecrona postulates as most significant to human behavior is of a different quality from Freud's. Olivecrona notes that "parents are anxious to instil obedience to the law into their children" ${ }^{20}$ and that "first indelible impressions in early youth concerning the relations to other people are directly or indirectly derived from the law." 21 But this is only remotely like Freud's emphasis on "primary group" (immediate family) experience as the most critical influence in social development. Freud stresses the importance of pleasures and pains in association with parents as the fundament in developing man's sociability. It is the character and intensity of personal experiences with parents, at some point leading to the solicitation of their acceptance and renunciation of asocial and anti-

15. Adler, The Practice and Theory of Individual Psychology (Radin transl. 1929).

16. Horney, The Neurotic Personality of Our Time 163 (1937).

17. Id. at 162 .

18. See Fromm, Escape From Freedom 140 (1941).

19. A compact but perceptive and analytical presentation of the basic theories of Freud is to be found either in HENDRICK, op. cit. supra note 13, or in BRENNER, op. cit. supra note 13. A capable comparative analysis and critique of more orthodox Freudianism and of the major deviationist psychoanalytic theories is presented by Munroe, Schools of Psychoanalytic Thought (1955).

20. Olivecrona, op. cit. supra note 1 , at 147.

21. Id. at 154. (Emphasis added.) 
social behavior, that produces proper inhibition and conformity in relation to authority. The process is one of evolution in the stage and condition of consciousness known as the "super-ego" 22 or, in its slightly advanced form, conscience. The emphasis, if not the intent, in Olivecrona's formulations appears different. Law appears to operate directly upon the human personality and only indirectly or incidently through the agency of the parent serving as a model for authority.

Law, in Professor Olivecrona's formulation, is experienced as an "idea," as thought and imagination, though sometimes reference is made to a "feeling" of "binding force." The content of thought is not substantially derived from personal experience but from a non-Freudian kind of introjection of social sentiments and attitudes. The capillary attraction resulting in this transference of law to the human being has an uncertainly defined source. Juxtaposed in relation to existing psychological theory, it bears some resemblance to Carl Jung's concept of the "collective unconscious." ${ }^{23}$ On the other hand, the source of attraction is viewed as tending toward a rational foundation. Partly, it is the awareness of external force that encourages and coerces lawful attitudes and behavior for primarily utilitarian reasons that can be accounted for in terms of behavioristic (stimulus-response) psychology. ${ }^{24}$

Professor Olivecrona has presented an exciting psychological theory. It is also one that encourages much speculation, in search of fuller substance, and much skepticism, seeking some firmer indications of validity and consistency. The particular process by which law affects the individual, the crux of Professor Olivecrona's jurisprudential thesis, is the matter that is the most open to study. One may reasonably ask, how, in fact, do psychological processes, i.e., ideation and emotion, bring law into focus and operate in the individual personality. Is consciousness of law as substantial as Professor Olivecrona suggests and does it in truth operate directly as a force taken from an essentially intellectualized view of social reality transmitted impersonally to the consciousness of the individual? Clearly, Professor Olivecrona is travelling pioneer psychological territory in this formulation. Is the rule of law vested with the element of strong and certain psychological symbolism, as he suggests and, were it so, is it of such strength as to

22. See Brenner, op. cit. supra note 13 , at $25-40$; see also Hendrick, op. cit. supra note 13, particularly 150-66. The basic and original reference in Freud is contained the THE EGO AND THE ID (1923).

23. See Jung, Two Essays on Analytic Psychology, particularly 67-82, 94-115 (Baynes trans1. 1928).

24. See mention of "stimulus-response" (learning) theory and references thereto in connection with the analysis of Professor Ross' psychological views at pp. 478-80 infra. 
activate an urgency of thought and action? These are the questions that may be posed and must be answered before Professor Olivecrona's psychological thesis regarding law can be taken comfortably.

\section{Alf Ross}

The psychological man of Professor Alf Ross ${ }^{25}$ misses the complexity of Professor Olivecrona's formula. With some uncertainty, however, this may be only a deceptive appearance for those readers who, like this one, are limited to English translations of Professor Ross' work.

Professor Ross' views appear to be singular in that he argues the psychological personality of man from what is prerequisite in a theory of law. Thus, he states as his first premise that "the science of law is a branch of the doctrine of human behaviour, therefore the legal phenomenon must be found within the field of psycho-physical phenomena constituting the domain of psychology and sociology." 28 There follows the conviction that "the natural starting-point for the delimitation is to be found in the existing theory of law, the method being to examine what realities must be assumed to underlie the rationalizations developed in this." 27

Conceivably, if Professor Ross took as his point of departure for psychological interpretation some other experience than that which relates to law, he might wish to change his formulations. On the other hand, it rings true that while the content of social experience might vary the formal view man takes of reality, the basic psychological processes involved in experiencing reality might be one and the same. In order to give substantial weight to Professor Ross' psychological theories the latter assumption must be made.

In Ross' view, man's attitudes, dispositions and, presumably, his actions, are the product of social learning. A prevailing social order tends to crystallize most experience in particular terms. The result, for the individual, is habit formation founded in the repetitive qualities and views that orderly social processes give to individual experience. Repetitions in experience and reinforcement of meaning and effect over a period of time crystallize habits to a point where the latter, rather than influences in external reality, largely underlie the course of behavior. Habit becomes transfixed within the individual into a symbolic manifestation, taking the form of personal "conviction." 28 Implicitly, the

25. See particularly Ross, Toward A Realistyc Jurisprudence (1946). It is his most complete jurisprudential tract in English.

26. Id. at 78.

27. Ibid. (Emphasis added.)

28. See $i d$. at 87. 
latter is a determinative factor in behavior and governs individual behavior tendencies. The individual acquires a "disinterested behaviour attitude having the stamp of validity" ${ }^{29}$ (social acceptability or practice).

In its connectedness to law, habit based upon regularities in social experience and symbolized in the form of "convictions" is the basis of "moral attitudes." It is these latter that generate much of the behavior tendency and response the individual gives to law-related matters.

Merely customary social processes do not render all human experience consistent and regular in nature and meaning. This Professor Ross recognizes in terms of "a possibility of no small individual divergencies," ${ }^{30}$ and, because of this, law in his formulations is given a more explicit role in human behavior. Matters for experience which lack a personal commitment in terms of certain moral attitude are resolved in terms of law. Cognizance of law as a coercive force, capable of compelling particular behavior, provides the second basis of disposition and behavior in Ross' theory. He refers to "an interested behaviour attitude, more precisely determined as an impulse of fear of compulsion." ${ }^{31}$ That which the individual does not adequately experience so as to evolve in terms of habit and conviction, is given a determined meaning and value in the words, actions and structure of law. The individual accepts the particular meaning and value because of the coercive influence that lies behind it. At the same time, this reinforces and enlarges a general law responsiveness which the individual derives from his "moral attitude."

Between the experience of custom and the effect of law, the individual's choice of attitude and response in social reality is made complete.

Professor Ross carries his psychological thesis one further step. $\mathrm{He}$ emphasizes the "inductive interaction between these two factors [law and custom or, in personal terms, "interested behaviour attitude" and "disinterested behavior attitude"] in such a way that the existence of the former tends to cause and stabilize the existence of the latter, and vice versa." 32 Acceptance of the law by the individual is a basic "moral attitude" conditioned and reinforced by the order and regularity arising from social experience. On the other hand, that order and regularity is to some extent determined and explained by the words, actions and structure of law reinforced as they are by the availability and exercise of force.

29. $I d$. at 78.

30. Id. at 87.

31. Id. at 78 .

32. Id. at 78-79. 
The individual generally undergoes regularities in his experience which lead to personal habits and "convictions." At the same time, law tends to resolve uncertainties in experience so as to generate habits and "convictions." The individual fears the coercion of the law and therefore tends to respond according to its terms, but he has also acquired the habit of obeying the law and reinforces this habit by observing the latter.

It is only the analytical framework that suggests independent sources in personal and social experience and attitude. The sources are, in fact, mutually dependent and cannot be identified as independently based and independently operative. Law and custom, or, in personalized terms, "interested behavior attitude" and "disinterested behavior attitude," have the relationship of chicken and egg.

As it best appears, Professor Ross offers a complete social determinism to account for individual behavior. The individual is entirely the product of the filtration of social processes. In the narrower terms of his own definitional framework, concerned specifically with lawrelated behavior, "behaviour attitude [is] evoked by social suggestion and the Pavlovian conditioning of reflexes." 33

Conditioning is a basic term, a basic process, in learning theory. It is, in fact, an important habitude of experimental psychology, so much of which pursues knowledge of the learning process. It is a characteristic of theories of learning that they only aspire to account for complex personal attitudes and actions, as in social situations, though theorists have developed essential apparatus for the purpose. ${ }^{34}$ The theory of learning that advances most closely to an account of substantial behavior is in the credit of the late Professor Clark Hull. ${ }^{35}$ Its own theoretical forebear is largely Pavlovian conditioning and its central concept is habit. Hull's is a complex set of deductions and postulates. In its most primitive essentials it takes into account sources of ability, drive and motivation within the individual. It notes with elaborate distinction the cues and stimuli that create a state of awareness and incite or direct behavior. It postulates with particularity the connection between awareness and subsequent behavior that accounts for regularity and habit, and states a basis for the explanation and prediction of personal action and attitudes. In terms of this basic sketchwork, Professor

33. $I d$. at 86 .

34. A fairly elementary presentation, analysis and critique of extant learning theories is given in readable form by Professor Ernest Hilgard. See HILGaro, Theories of LEARning (2d ed. 1956). See also the more advanced analysis of major learning theories in Estes, Modern Learning Theory (1954).

35. See Hull, A Behavior System (1952) ; Essenttals of Behavtor (1951); Princtrles of Beravior (1943). A layman who proceeds to the reading of Hull should do so with trepidation. He does not address himself to the general reader. 
Hull's theories differ from those of other estimable modern learning theorists only in that they are more complete, more extensively developed and give greater and clearer articulation to each of the essentials of learning. It is with respect to the development of the concept of drive, and speculation as to its variety and sources, that modern learning theory differs essentially from Pavlovian conditioning and, unintentionally perhaps, from the now primitive, more familiar behavioristic formulations of John B. Watson. ${ }^{36}$

Professor Ross appears to be on the same track as the learning theorists though, in his enthusiasm for his psychological interpretations, he has failed to give us the benefit of an accounting concerning the steps by which the interpretations came about. Psychological elaboration in a jurisprudential tract is a burdensome detail and one can properly fit in interstices in formulation with available and familiar knowledge. That is, one can if one has all the sufficient elements of theory in bolder outlines. The social stimulus to behavior, the development of habits and patterns of behavior through a process of social reward and punishment continually reinforced, is bold to see in Professor Ross' theory, though only in general terms. What is notably lacking is a concept of energy and drive that at least initially underlies and propels behavior, some notion of individual substance or experience that sets one man apart from others. As is, man appears as a responsive agency but for no cause or reason beyond the mechanical application of social forces.

Professor Ross' psychological man seems strikingly a psychological oddity whose identity is lost in social processes. Lacking is an urge to experience, a sensate structure of personality that differentiates man from his environment and gives him personal integrity, a person whose identity can be established in terms of some characteristics of individuality.

Taken as a real live specimen, Professor Ross' entity of man is not wholly convincing. It passes too easily as an incidental by-product to some larger framework of interest and theory that purports only to assume, without attempting to know, what sort of creature psychological man is. Professor Ross has said as much. ${ }^{37}$ Stretching his thought so as to bind historical and psychological concepts of law, he states

"fossilised concepts [of law] can be demonstrated, and the entire modern mentality is permeated by archaic elements, deposited, so to speak, in geological strata, so that side by side with

36. See Watson, Psychology From the Standpoint of a Behavrorist (2d ed. 1924).

37. See text accompanying note 27 supra. 
elements which are the glorious sign of the victorious power of the human spirit, we meet with forms that open perspectives down to the darkest prehistory of mankind." 38

Professor Ross has perhaps accomplished his purpose in conciliating historical and psychological concepts of law but, one might say, a little too easily. He has become the prisoner of one of the most controversial and questionable concepts of Jungian psychology, the "collective unconscious" that mysteriously ensnares the history of human experience in the individual and operates upon personality and behavior from afar inside the human being. ${ }^{39}$

\section{ANDERS VILHELM LUNDSTEDT}

The psychological theories of Professor Lundstedt ${ }^{40}$ verge upon anomaly in a jurisprudential setting. In their essential character they demonstrate a greater affinity to the dominant psychiatric views of modern times than they do to the traditional habits of thought about psychology that seem to permeate law and jurisprudence.

Professor Lundstedt propels into the heart of his jurisprudence a conception of man as a creature of powerful instincts and impulses, one who is given to strong feelings and emotions that may dominate his behavior. It is the conative influence and the emotional attitude of man, rather than his habits of rationality and his capacity for thought, that characterize his essential being. They mold his dispositions and responses to his environment. The cognitive elements of personality have only an intermediate effect in man's adaptations in life. At best, they pale in significance next to the power and importance of instinctual and emotional life.

Lundstedt speaks of "psychological impulses arising in various ways from the nature of man, his senses, his instincts and his emotions. These psychological impulses operate as mainsprings for man's actions, and his actions in turn have a multitude of psychological as well as material consequences." 41 In what seems to be the most proper interpretation of the term "impulse" as it is used here, it consists of dispositions to behavior deriving from man's biological character.

There are but adumbrations on the intelligibility of these biological forces. Apparently, some instincts, at least, have a sociable temperament. Professor Lundstedt refers to "powerful moral instincts" 42

38. Ross, op. cit. supra note 25 , at 15 .

39. See authority cited note 23 supra.

40. See particularly LundSTEDT, Legal ThINkINg Revised (1955).

41. Id. at 8 .

42. Id. at 124 . 
and "infers or conjectures" that there is in man "a social or communitybuilding instinct." 43

Emotion, in contradistinction to reason, is the essence of some, if not all, experience, and reason without an attached emotion either may or must be sham. Thus, quoting Professor Lundstedt, "the significance of the abstract legal conceptions of the common sense of justice lies in their power to call forth feelings in agreement with their contents. . . [O]ne cannot believe in the reality of what one says if this is not supported by the feelings." ${ }_{44}$ Put roundabout, a common sense of justice represents one value judgment and, Lundstedt notes, value judgments are expressions of feelings.

The role of cognitive skill in Professor Lundstedt's thesis is to provide conception as a cue and a more definable basis for emotional expression. "The feeling [of value] is directly brought to life . . . by the person's conception [of the thing of value]." 45 "It is our very conceptions of reality which lead to those feelings for which the value judgments are expressions." 46 Emotion apparently becomes animate through the operation of powers of reason, and it is not clear whether feeling is or is not included in the process.

Though man's instincts and emotions provide his essential energy and disposition, Professor Lundstedt observes that these are harnessed to, used by and even come to serve law and social life. "The group life of our species is made possible by 'law.' In point of fact 'law' is an intricate machinery which is essentially kept going . . . by means of psychological impulses." ${ }^{47}$ And, at another point,

"[there is] pressure on the conduct of man brought about-thanks to certain reactions effected with a certain regularity on a number of modes of conduct-partly through conscious feelings of duty in the person acting and partly through powerful moral instincts in him engendered immediately through the socio-psychical pressure from the entire environment's collected feelings of duty in respect to [particular] conduct." 48

Apparently, the pressure of social force is brought to bear on man's consciousness, on the one hand, and also directly upon his instincts without passing through consciousness, on the other.

Only enough of Professor Lundstedt's psychological thinking is available to suggest the boldest outlines of his theory. These are

43. Id. at 128 .

44. Id. at 162 .

45. Id. at 47.

46. Id. at 200 .

47. Id. at 8 .

48. Id. at 124 . 
sufficient to identify Professor Lundstedt in terms of kinship with psychoanalytic traditions, at least in his emphasis on both instinctual and emotional life. In his emphasis on the importance of emotions in behavior he particularly shares the predilections of virtually all psychiatry.

It is in the development and details of his theory that Professor Lundstedt either deviates from his psychological fellows or fails to make clear his relationship to them. Lundstedt finds, where the psychoanalysts generally do not, that some instincts, at least, have aims parallel and consonant with political and social objectives. Either because of these instincts, or the powerful burden of social experience, or because of some other unarticulated basis of faith, Professor Lundstedt seems quite sanguine in his view that man's instinctual life and emotional dispositions for the most part bend naturally and easily in the direction of law and social order. However, this may only be a deceptive implication resulting from a lack of detail in Professor Lundstedt's theory. In fact, it is in the seeming embellishments that one could have learned from Professor Lundstedt how, if he meant it, instincts experience social reality without the latter passing through consciousness. How, in other words, is instinct expressed other than in terms of feelings that are related through some process of consciousness. And what, in clearer terms, is the fuller relationship of feeling and thought.

Professor Lundstedt's general thesis is provocative, if only because of its radical departure from more typical views of psychology that exist explicitly or implicitly in jurisprudence. However, it is in the substance of its detail that the earliest test of its probity lies.

\section{AXEL HÄGERSTRÖM}

The preceptor of the Scandinavian psychological jurisprudents, Professor Axel Hägerström, materializes the basic viewpoint of the group. The essence of law is not its identity and characterization in social and physical reality but its phenomenal qualities as a part of the psychological processes of man. He begins with the proposition that there are a

"series of feelings, propagated by inheritance through thousands of years, which are attached to rules for the community. . . . This group of feelings is of two kinds: it consists partly of feelings of duty in regard to the restrictions which affect one, and partly of specially intense feelings of power in regard to the acquisition of advantages which the rules of law assign to one-self and which are regarded as rights." 49

49. Hägerström, Inquiries Into the Nature of Law and Morals 15 (Olivecrona ed. 1953). 
There is postulated in addition a third feeling, operative when an individual is involved in the infringement of another's rights, "fear of reaction from one's neighbors." 50

These feelings are conceived to be the mortar of the law. As Professor Hägerström puts it in grandiloquent fashion, "And so the whole legal machinery works, driven by a mighty complex of feelings, which function independently of the views on what laws ought to be established." 51

Duty, in Professor Hägerström's view, is a state of consciousness within the individual, ${ }^{52}$ more correctly identified as a "feeling of duty." It is "a conative feeling . . . a feeling of being driven to act in a certain way." 53 Further, "the impulse imposes itself on us, no matter what evaluatory attitudes we may take towards the action." 54

Hägerström expressly rejects the view that a feeling of duty is the result of a fear of personal consequences, or of a standard and value that stands without the individual and transfixes itself upon him. ${ }^{65}$ The feeling of duty appears to be a powerful drive or instinct, existing or conditioned beyond the quick reach of reason and, as such, a prime mover of man's conscience. ${ }^{56}$

Reduced to terms of finer analysis, the feeling of duty consists of the "simultaneous association" of different states of consciousness, notably the "association of a feeling of impulse and the idea of an action, in which the former receives its special expression." 57 The feeling and the idea are coordinated by means of language. Language, and notably the indicative form of sentence in which the concept of duty takes place, evokes the association. The sentence in the indicative form is a "reflex which arises unconditionally from the underlying state of consciousness," 58 and is similarly experienced by a large group of persons because of their membership in "a social linguistic community." ${ }^{59}$ It is language which connects the "feeling of impulse" with an "idea of action" that is representative of the action itself. As Professor Hägerström further explains, "the idea of the determinate character of the action is predominant at the time when the speech reflex operates, and it forcibly
50. Ibid.
51. Ibid.
52. See $i d$. at 127.
53. $I d$. at 130 .
54. Ibid.
55. See id. at 128-30.
56. See id. at 131-32.
57. Id. at 132 .
58. Id. at 138.
59. Ibid. 
inserts the expression of the feeling into the expression of the determinate character of the action." 60

"Conative impulses," the enervating drives that produce the feeling of duty, emanate from two sources: command and habit. ${ }^{61}$ The psychic potency of command relates in large part to the influence command holds over the individual because of his early and continuous experience with authority. Professor Hägerström cites, as predispositional to the individual's response to command generally, his experience with parental authority, with law, with religion, and the like. ${ }^{62}$ There exists between the commanding party and the commanded "special relations . . . a superiority in power on the part of the former which makes the latter susceptible to his influence." 63

The long term cultivation of response to command, induced at least partly by the painful effects resulting from a failure to obey, ${ }^{64}$ results in an unconditional tendency to compliance with the requirements of a statement issued in the imperative. "An expression in the imperative. . . effects an association between a feeling of conative impulse and the idea of a certain action." 65 In effect, it creates a feeling of duty, "an intention to act in a certain way." 66 The imperative may arouse the "idea of a certain action . . . and repress all conflicting ideas" ${ }^{\circ 7}$ where the relations between the parties are clearly superordinate-subordinate. Where no conflicting ideas exist the imperative merely reinforces and activates a prevailing view and tendency. ${ }^{68}$ Where there are such, "the imperative form acquires its peculiar meaning." It is utilized "to suppress the tendency of these impulses [ideas] to materialize in actual intentions, by producing through the imperative form an intention to carry out the action commanded." 69

Habit, the second source of "feelings of duty," appears not to be substantially different from command. In his analysis, Professor Hägerström conceives of habit in terms of custom and ascribes to the latter the force and influence of command in a person's behavior. ${ }^{70}$ The possibility of competition between the commanding influence of custom and of authority is recognized though it is Hägerström's view that, in
60. Id. at 135 .
61. See id. at 152 .
62. See id. at 153.
63. Id. at 120-21.
64. See id. at 153.
65. Id. at 120 .
66. Ibid.
67. Id. at 121 .
68. Ibid.
69. Id. at 122 .
70. See id. at 155 . 
advanced societies, commanding authority tends to predominate over custom in "forming the system of conduct." 71 He notes that where the two, custom and authority, are coordinate, the individual is better able to evolve a correct standard of behavior (i.e., call forth an appropriate "feeling of duty") for most, including idiosyncratic, situations. This ability is the mark of "the development of moral consciousness." 72

Feelings of duty, then, are a resultant of feelings (of power) associated with command. However, they are differentiated in that feelings in relation to command exist only in terms of some immediate interpersonal relationship in which one party is presumably known to be clearly in power, and they are aided by the emotional impact of the imperative form of language. Feelings more strictly connected with duty, on the other hand, operate and exist independently of personal direction and appear to be the proximate result of the psychological power and skill of the symbolic forms of language itself. Feelings of duty appear as a more advanced and permanent form of civilized conception of law. Feelings in relation to command appear to hold more native power.

Another element of Professor Hägerström's psychological formulation is his explanation of a differently oriented basic feeling in relation to law, the "fear of reaction from one's neighbors." 73 The latter feeling results, not from the observation and experience of the effects of improper behavior, but from powerful impulses independent of the latter and bound to the feeling of duty. The feeling of duty regarding one's own behavior contains one's idea of the "rightness of an action." This "rightness of action," in Hägerström's view, applies equally to oneself and to others. ${ }^{74}$ In conceptual terms, there exists "a feeling of conative impulse, devoid of valuation, in respect of another person's action as right." 75 On this account, there exists what is commonly known as moral indignation and the basis for the demand upon others to respect one's own and another's rights. ${ }^{76}$ When the "rightness" of an action is not respected, and a right has been infringed, it is the analogue of a feeling of duty that has been violated. ${ }^{77}$ The spontaneous reaction to the disesteem and moral reaction that results is a feeling of anger. Further, the cumulative recognition that commanding authority exacts reparations, learned in connection with the

71. Id. at 156 .

72. Id. at $156-57$.

73. See text accompanying note 50 sipra.

74. See Ḧ̈GERSTRÖM, op. cit. supra note 49, at 170.

75. Id. at 171 .

76. See $i d$. at $172-73$.

77. See $i d$. at $171-72$. 
development of the feeling of duty, gives rise to the idea "that one ought to make reparation for damage . . . if claimed," 78 and to the idea "that compulsion will be exerted, if reparation is not made voluntarily." "79 The psychological process in the feeling of justice is identical with that of the feeling of duty to which it is linked. There is "a feeling of conative impulse, devoid of valuation, linked with [the idea of justice]." 80 "The idea of compulsion . . . is [of] something owed by the wrong-doer." 81 The ideas of justice that are involved are essentially revengeful in character, ${ }^{82}$ though they may be attuned to social needs and interests. ${ }^{83}$ At base, they emanate from the instantaneous feelings of anger that are exhibited toward a failure to observe the rightness of an action. The feelings of anger, taking the form of aggressive counter-action, are self-preservative in character. In the form of measured self-preservation, where they do not constitute a mere reflex action, they underlie the demand for suffering and the ideas of justice which Hägerström describes. ${ }^{84}$

Basically, the feeling of "fear of reaction from one's neighbors" appears to represent that others, as well as oneself, bear similar "feelings of duty." Secondly, the violation of feelings of duty results in feelings of disapproval and revenge, with concomitant effects, that can occur with equal spontaneity in others as well as in oneself. The latter is a troubled or uncomfortable feeling with unpleasant effects, a kind of feeling that one seeks to avoid, perhaps more notably as it is held and applied by others.

While at first Professor Hägerström makes mention of "feelings propagated by inheritance," 85 his prevailing view seems to be that man, through processes of conditioning that occur early and continuously, acquires drives of a particular sort. The conditioning influences are experiences with authority and with convention. The resulting drives take the form of powerful anticipatory responses, conditioned so that they function autonomously and without reason, in the face of expressive authority. The anticipatory response is in the nature of a feeling of duty and contemplates compliant action. Intervening between the feeling and the contemplation of action is the symbolism of language. Language acts as a catalyst, having the ultimate effect of

78. $I d$. at 177 .

79. Ibid.

80. Id. at 179 .

81. Ibid.

82. See $i d$. at 188 .

83. See $i d$. at 178, 182.

84. See id. at 188-91.

85. See text accompanying note 49 supra. 
connecting emotion to thought so as to impel action. The connecting process is not deliberate but seems to occur in the form of a mechanical association.

Professor Hägerström views the above-mentioned drive as common to humanity. Through it there apparently evoke the keen senses of obligation or prerogative that are, inferably at least, so nearly the converse of one another. When the drive fails to appear, notably in others, there are instant discomfort and attendant feelings of anger. Further, earlier conditioning in relation to authority creates the expectation that, when this situation arises, authority will exact an ounce of flesh from the deviate, if the latter fails to make suitable amends himself. The response of authority is viewed as essential to preserve and maintain the character and presumably the intensity of the drive in the rest of humanity.

Professor Hägerström would probably find a very comfortable place in the den of the learning theorist. ${ }^{86}$ Learning is the hallmark of his thought about the law. It is the inductiveness leading from experiences in his social environment, and the constant and consistent reinforcement of experience, that lead to man's dispositions and behavior in relation to the law. The latter take on the form and intensity of a drive. At the same time, Hägerström emphasizes the importance of an influence that is more familiar and better known to a variety of psychoanalytic thinkers, the cardinal importance of authority in shaping behavior. ${ }^{87}$ And then, finally, Hägerström's recognition of the importance of the symbolic process as a psychological element identifies him with the community of individuals who stress the psychological role of language and of communication in the evolution and explanation of behavior. ${ }^{88}$ Language, by many of these individuals, is seen as a form of psychological expression, reflecting and inducing a frequently predictable variety of psychological and behavioral reactions. 89

The largest difficulty with Professor Hägerström's theory is in the accounting for deviancy. Since feelings in relation to duty are so intense and pervasive an element in human experience, and seemingly are a universal characteristic in man's behavior, one may inquire as to the basis for any deviation. There is in this question an implication that Hägerström's theory, to be useful, must better delineate the psy-

86. See notes 34,35 supra and accompanying text.

87. See notes 15-19 supra and accompanying text.

88. See particularly Korzybskr, ScIence and Sanity (1933); cf. Morris, Signs, Language and Behavior (1946); SaprR, Language and Personality (1949).

89. In this connection, see the learning theorists' approach to language, as in Osgood, The Measurement of Meaning (1957). 
chological characteristics that attach to any range or kind of social experience. In effect, this is almost at the beginning of any psychological theory of behavior that takes as an important element the influence of social reality, and the theory can have only limited moment without it.

Somewhat along the same point one would inquire what other drives of man achieve some appurtenance to his law-related dispositions and behavior. As Professor Hägerström presents his thesis, behavior connected with law seems to be the outgrowth of only one kind of disposition and one general type of situation operating essentially in isolation and without competition from other areas or experience of personality.

And then, lastly, one wonders about the purely mechanical nature of the process that enfaces one with law. Particularly, are linguistic symbols mere automatic conduits or is their choice and operation a more complicated matter?

Like his Scandinavian brethren, Professor Hägerström has much to say and still more to answer.

\section{Leon Petrazycki}

The polymorphic psychology of the Scandinavians evinces a common faith, that law is neither an external nor a by-product in man's most intimate experiences. In fact, law appears as a fundament of individual human growth and behavior, so much so that it is indistinguishable as an independent property. It may be reasonably specific in appearance but it seems often not to be clearly separated from the variety of man's inclinations and the general pattern of his social behavior.

Joining in the essential faith that law is, at bottom, a psychological phenomenon, is the Polish law professor and contemporary of the Scandinavians, Leon Petrazycki. In Petrazycki's own phraseology, "Legal phenomena consist of unique psychic processes expressed in the unique form of ascribing to different beings, or to certain classes of such beings, 'duties' and 'rights.' " 80

Stressing the need for "a scientific concept of law," 91 Professor Petrazycki would plumb the psychic processes in order to identify and, in turn, to classify legal phenomena. His image of science is in the Aristotelian tradition of "developing proper concepts of different classes of objects," 92 through the orderly arrangement of facts relating

90. Petrazycki, Law and Morality 8 (Babb transl. 1955). See generally id. at 6-12.

91. Id. at 3.

92. Ibid. 
to these objects. ${ }^{93}$ His selected method of study is essentially "selfobservation: the introspective method," 94 "the proper, and the only possible, method of observing legal phenomena." ${ }^{95}$

Professor Petrazycki premises that only man, of all creatures, is "distinguished by the capacity to experience the complicated psychic processes which constitute legal phenomena." 96 Further, "the capacity to experience psychic processes of the legal type . . . emerges only with the attainment of a certain level of culture. . . . Only those persons who have attained a certain age, and been subjected to certain educative influences, have that capacity." 97 The capacity, barring physical or psychic defect, occurs fairly early, before coming of legal age. ${ }^{98}$

With the assertion of this foundation of belief, Petrazycki next offers an original blueprint of psychological experience. There appear to be two fundamental dimensions in his schema. ${ }^{99}$ Psychological experience is, firstly, either "unilateral" or "bilateral." The apparent distinction is that the unilateral type involves the sensitivities and inclinations of the experiencing organism, with only incidental reference to the role of the surrounding environment and the effect upon it. In "bilateral" experience a stronger contemplation of the organism in relation to its environment is afforded. It would include, either tacitly or by direction, expectations, demands and obligations that are to be met and satisfied in relation to objects of the individual's surrounding environment, and are comprehended as important to both the individual and the environment.

Secondly, psychological experience is of two varieties, either "passive" or "active." Reference. to "passive" experiences suggests that what is meant is that individuals merely receive and register, and react their awareness to whatever is taking place. In "active" experience, the individual is inclined to go further and utilize motive and will to extend or enlarge what is happening.

Feelings, meaning pleasures and sufferings, are "unilateral-passive" in Professor Petrazycki's blueprint. ${ }^{100}$ "Will experiences," such as "the will to work regardless of fatigue," are "unilateral-active ex-

93. Cf. text at pp. 493-95 infra.

94. Petrazyckr, op. cit. supra note 90, at 13.

95. Ibid.

96. Id. at 12.

97. Ibid.

98. Ibid.

99. See id. at 22-24.

100. See $i d$. at 22 . 
periences." 101 Hunger, thirst and sex excitation Petrazycki classifies as "passive-active, bilateral experiences." 102

Advancing his fairly elaborate lexicon one further step, Petrazycki refers to all phenomena of a "bilateral passive-active nature" as "impulsions." 103 "Impulsions act as the principal and directing psychic factors of adaptation to the conditions of life." 104 It is primarily in the realm of the impulsions that one is to make significant findings regarding legal phenomena.

"Impulsions," the well-springs of human action, are distinguished by a great diversity of source and quantity. Highly sensitive and elastic in the face of experience, their intensities vary with the character of the events they undergo. ${ }^{105}$ They serve hedonistic designs but may equally well serve utilitarian or other purposes. ${ }^{106}$ Though sometimes deliberate and purposive to an immediate circumstance, they may, for example, reflect a nearly automatic response aroused by past purposes and experience. ${ }^{107}$ They may reflect the established association between particular behavior and specific objects and events, to the degree that the pertinent behavior occurs virtually reflexively. ${ }^{108}$ Furthermore, and of particular note in the area of moral and legal behavior, they may represent instantaneous value judgments aroused by particular behavior and lending themselves to unambiguous thoughts and actions of a clear-cut ethical quality. ${ }^{109}$ The judgments, presumably, mostly align themselves in normative fashion, and are referred to by Professor Petrazycki as normative judgments. ${ }^{110}$

It is Petrazycki's thesis that moral and legal situations provide the instance for a set of impulsions-experiences of duty and obligation -which he describes as ethical impulsions, ${ }^{111}$ impulsions that are "unilateral-imperative" (moral) or "imperative-attributive" (legal).112 It is these, operating normatively but as yet largely unidentified, that largely influence our behavior in the legal and moral situations.

Professor Petrazycki would advance the science of law on the psychological framework that he has outlined. He proposes to apply

101. Ibid.

102. Id. at 22-23.

103. Id. at 23.

104. Ibid.

105. See id. at 24.

106. See $i d$. at 28.

107. See $i d$. at $28-29$.

108. See id. at 29-30.

109. See $i d$. at 30 .

110. Ibid.

111. Id. at 35 .

112. See id. at 49. 
the method of introspection to sample ethical response inclinations, or impulsions, in situations "in the field of duty consciousness." 113 The character and intensity of ethical impulsions could thus be assessed and, he feels, could be done so with great skill and certainty where the situations to be judged arouse conflict or provocation and bring to the fore more clearly the contending ethical value. ${ }^{114}$ Since ethical impulsions offer a particularly strong constraint upon overt behavior, ${ }^{115}$ their identification is of great moment to an understanding of the character and operation of legal processes.

In the compass of Professor Petrazycki's theory, ethical impulsions, of both the legal and moral denominations, embrace a broader scope of experience than may meet the eye. They are to be found, in the instance of law, not only in relation to formal and official authority, decision and institutions but also in a variety of experiences that are usually not connected with law. The playing of games, ${ }^{116}$ the observance of rules of courtesy and etiquette, ${ }^{117}$ intimate relationships that generally fall outside of the scope of legal regulation, ${ }^{118}$ provide additional instances where "law," in Petrazycki's sense, operates. In fact, any situation or relationship where an individual feels something in the nature of a compulsion or obligation to behave in a particular way toward certain others and objects in his environment affords an ethical experience and the basis for detecting ethical impulsions. There is, further, differentiation in detail between the psychological meanings and consequences of "unilateral-imperative" (moral) experiences and "imperative-attributive" (legal) experiences. ${ }^{110}$

The powerful intuitive bent in Professor Petrazycki's concepts and theories relating to law is plain to see. Experience of an exceptional variety is the touchstone for the issuance of "impulsions" or tendencies to respond that take on a certain and definite character. Impulsions, particularly the legal variety, are a large, if somewhat cryptic, force in man's personality and behavior. They define his intellectual attitudes and may also guide his more demonstrative behavior. They are the bedrock on which a highly articulate, orderly and successful conception of law, formal or otherwise, can be built. And the conception is for the taking if one will adapt the appropriate method, in this instance introspection, for their detection and study.

113. Id. at 36.
114. Ibid.
115. See $i d$. at $37-45$.
116. See $i d$. at $64-65$.
117. See $i d$. at 65.
118. See $i d$. at 67.
119. See $i d$. at $93-137$. 
Petrazycki's theory seems a fusion of the newer and the older fashioned psychology. His genius sensed and applied a tradition of the twentieth century, with its emphasis on the important role of the elements external to the individual (the environment) in inducing and perhaps molding behavior. Simultaneously, the flavor of the nineteenth century "faculty" psychology ${ }^{120}$ also afflicted his thought. His notion that impulsions are discretely organized in terms of character, have and maintain clearly separable identities, and then compete with one another within the individual is the tacit evidence of an older view in psychology.

Professor Petrazycki's consciousness of method and stern desire for the rigorous acquisition of knowledge, carefully traced to its source for validity, give him the stamp of a scientist that is not a familiar quality among his jurisprudent brothers. But the anomaly of his thinking does not hold only in comparison to his legal fraternity. His cardinal concept of behavior, "impulsion," has the intuitive flavor associated with some psychiatric and psychological theories of behavior. Freud's is the most notable in this respect, and Professor William MCDougall's, with its emphasis on a variety of "social instincts," ${ }^{121}$ is another worthy of mention here. Yet his penchant for systematic experiment will permit his identification with the school of psychologists, most notably students of learning behavior, whose hallmark is empiricist methodology and rigor. And finally, adding to the singularity of thought, Professor Petrazycki's preferred method of study, introspection, identifies him with Titchener's long-discarded emphasis on a similar method by a similar name. ${ }^{122}$ It does not connect him with the higher development of empirical methods that is associated with the learning psychologists, nor with the particular observational methods of such as the Freudians, who developed free association to study elements of consciousness.

Petrazycki's psychological concoction is the stranger and the more remarkable if, as it appears, his situation and station in eastern Europe might have contributed to his isolation from burgeoning developments in psychology in the rest of the world about and after the turn of the twentieth century. Remarkable as the case may be, though, it is not the heterodoxy that provides the difficulty with Petrazycki's thought. One would want to know much more about the concept of "impulsions,"

120. See text infra and at pp. 494-95 infra. 1923).

121. See McDougall, An Introduction to Soctal Psychology 20-93 (15th ed.

122. For a brief description and discussion of the Titchenarian "school" of the turn of the twentieth century, one may consult a highly readable treatise on the varieties of psychological thought: HEIDBREDER, SEvEN PSYCHOLOGIES (1933), or a more recently revised presentation of schools of psychological thought, WoonworTH, Contemporary Schools of Psychology (rev. ed. 1948). 
whether they are biological, social or metaphysical in basis, what is the range of their character, and their relationship to one another, and more of the circumstances that make for their change and adaptation to events. As it stands, the concept seems mostly heuristic and invites but limited confidence that there are real life equivalents for the concept of "impulsions." Since the classification of impulsions is the essence, and seemingly most of what there is in Petrazycki's psychological underpinnings for law, his theory rests almost squarely on the validity of this single concept.

Most easily preserved in Professor Petrazycki's thought, ironically perhaps, is his emphasis on validity in defining and observing the character of law. His own psychological explanations relating to law lack evidence or amplification to demonstrate that they have merit. Yet, he emphasizes the need for the systematic accumulation of evidence as a basis for knowing the full nature and character of law.

Scandinavian jurisprudential psychology, particularly, and Petrazycki's to a lesser extent, share the bias of all modern psychology. It seeks the explanation of behavior in terms of intertwining sets of operations distributed in time. It is, in a term, process-oriented, in the traditions of science dating from Galileo. For the most part, it is emotional capacities, connected with intellectual and ethical dispositions because of and in the course of each individual's social experience, that govern man's law-abidingness and his relation to law. Law has meaning only as it reflects and relates to man's capacities, his dispositions and his intimate experience.

Sharply contrastive is the kind of psychology that generally permeates the law. Jeremy Bentham may be taken as the sovereign exponent of the view. System, for behavior, is a matter of fixed properties in the individual. Behavior is meaningful only in terms of effects, and declension into an encyclopedia of behavior elements serves as analysis. The scientific tradition is that mostly identified with an earlier period, beginning with Aristotle. The purely descriptive technique assists classification and serves better as a means to the immediate judgment of behavior than as an aid toward its prediction. Intellectual and moral skills and knowledge are recognized as the eminent and powerful sources of behavior, though Bentham, for one, owned to the need for a larger study and classification of "the will." ${ }^{123}$ The conceptual arrangements between law and behavior are the product of the drawing board, ordered in terms of logic, symmetry, or arithmetic. They are based on articles of faith concerning man, that he 1823).

123. See Bentham, Principles of Morals and Legislation at xiii (rev. ed. 
possesses a moral faculty which guides and controls his behavior, that his native dispositions are law-abiding or, at the very least, that his intelligence, narrowly construed in terms of intellect, recognizes the merit of observing the law. It is psychological subsumption of this kind that settles a relationship between man and law. In a purely conceptual sense, however, man and law are entities apart.

\section{Jeremy Bentham}

Bentham's psychological man is born to the mold of the older psychological tradition. Appraised solely in terms of the effects of his behavior, man is governed by an ethic, Bentham's particular ethic being postulated in psychological terms. It is the familiar "principle of utility," 124 "that principle which approves or disapproves of every action whatsoever, according to the tendency which it appears to have to augment or diminish the happiness of the party whose interest is in question." 225 And so, "nature has placed mankind under the governance of two sovereign masters, pain and pleasure." ${ }^{126}$ The variety of pleasures and pains are separately catalogued, ${ }^{127}$ denominated in such terms as (the pleasure or pain of) the senses, amity or enmity, skill or awkwardness, piety, and the like, and are given genesis in the flow of physical, political, moral and religious sanctions. ${ }^{128}$

Pains and pleasures are viewed as "interesting perceptions" 129 and "the disposition which anyone has to feel such or such a quantity of pleasure or pain . . . is what we term the degree or quantum of his sensibility." 130 Sensibilities are subject to individual differences resulting from a variety of influences. These latter are separately identified and catalogued as physical and mental structure, body integrity and strength, characteristic intelligence and knowledge, established moral and social sensitivities and biases, habits and regular activities, interest in and accumulation of wealth, and established patterns of social preferences. These in turn are catalytic agents for such additional influences as age, sex, education, social position, and the like. ${ }^{131}$

The concern of law is, at best, only remotely with man's sensibilities. It more directly recognizes the social effects of his behavior and weighs these in terms of carefully circumscribed physical and psy-

124. Id. at 1.

125. Id. at 2.

126. Id. at 1 .

127. See id. at 33-42.

128. See id. at 24-28.

129. See id. at 33.

130. Id. at 44.

131. See $i d$. at 43-69, and particularly Bentham's own summary at 68-69. 
chological circumstances attending human actions of legal consequence. Act and circumstance, intentionality and consciousness, and, to a lesser extent, general disposition and specific motive are the conceptual matter with which law views and characterizes man's behavior. The perspective is more deliberately attuned to the needs of legislative mechanics than to the realities of human behavior. Acts and circumstances are given simple logical definition. ${ }^{\mathbf{1 3 2}}$ Intentionality refers to the purpose of the particular behavior (act), as it is determined by its proximity to the latter, and as it may be logically inferred from and contemplated by the consequences of the act. ${ }^{133}$ Consciousness refers only to the correctness and the completeness of social perceptions, as recognized in thought, that are relevant to the behavior and circum-

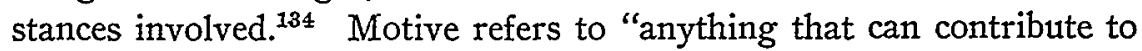
give birth to, or even to prevent, any kind of action" 135 in a "thinking being." 136 Motives are entities whose classification corresponds roughly to that of pleasures and pains. ${ }^{137}$ Disposition is a moral evaluative measure of man. It is, according to Bentham, "a kind of fictitious entity, feigned for the convenience of discourse, in order to express what there is supposed to be permanent in a man's frame of mind." 138 It is inferable from a judgment of the motive of a person's act and of the tendency of the act to produce pleasure or pain. ${ }^{139}$ Logic in the order of a person's behavior and consistency through time are assumed as a basis for judging a person's disposition from any particular act. ${ }^{140}$

The aim of Bentham's psychological man is pleasure. Perceptions of pleasure are conditioned by the dispositions resulting from the ordered accumulation of experience and from native endowments or faculties. From so much as is articulated in Bentham's theoretical framework, man's consciousness consists of one dimension and that regularly within the range of his intellectual and moral awareness. A failure of this consciousness results, not from any primeval and hidden forces underlying behavior, but from errors in social perception as a result of deficiencies in social experience and in endowment. It is the thinking apparatus, or faculty, that appears to serve man's psy-

132. See id. at 71-80.

133. See id. at 71, 82-88.

134. See id. at 71, 89-96.

135. Id. at 97.

136. Ibid.

137. See id. at 105-18.

138. Id. at 131 .

139. See id. at 134-35.

140. See id. at 133. 
chological purpose and his moral and social inclinations, though, interestingly, it is by feeling that he assesses the nature and quality of experience. ${ }^{141}$

Bentham's "principle of utility" bears a comparison with Freud's "pleasure principle." ${ }^{142}$ Both the political thinker and the psychologist view man's personal happiness as the guiding object in life. For the political thinker man's pleasures are several and distinct. They stem from the great variety of his endowments and social experience. For the psychologist, pleasure is basically sensual. It may, however, be delayed, detoured, disguised and diluted accordingly as the social order and social experience of the individual produce these effects on direct sensual and physical expressions and gratification. In Freud's view, man struggles that he may achieve biological pleasure devoid of contaminating social influences but, in the end, he makes his share of compromises with social reality. Pleasures, and they become several, diluted and diffused, take on social as well as biological forms.

In his psychological views Bentham appears to have woven the thought of a number of students of behavior of his and an earlier age. ${ }^{143}$ One can detect Aristotle's emphasis on the role of the intellect, and on its service in establishing and maintaining man's moral character. One can see the fortification of the element of reason in man's social behavior through the influence of Hobbes. The psychological empiricism of seventeenth and eighteenth century British scholars and adherents also appears to have made its mark on Bentham's psychological thought. There is, most notably, Locke's and Berkeley's emphasis on the study of man's behavior in terms of the experience of the senses, and the proposed systematic ordering of experience in highly rational terms as afforded in the thought of Kant. These, and undoubtedly other influences, mark Bentham's psychology as the creature and the captive of the major intellectual trends in its time.

The essence of a modern criticism of Bentham's psychological views is that behavior does not exist but it is determined. It is the facts, or the theories, relating to its determination that give its descriptive features meaning and probity. One would ask of Bentham

141. See quote from Bentham relating to sensibilities for pain and pleasure cited in text accompanying note 130 supra. 1958).

142. See Hendrick, Facts and Theories of Psychoanalysis 95-101 (3d ed.

143. The development of the study of psychology, notably through the culling of the thought of distinguished philosophers and scholars through time, affords the best means of viewing the evolution of ideas in the field. Bentham's psychological thought is best analyzed and appraised in terms of just such an effort. This can be most easily and conveniently accomplished by reference to treatises on the history of psychology. See particularly BRETT, History of PSYCHOLOGX (Peters ed. 1953); cf. authorities cited note 122 supra. 
today what are the sources of the separate psychological entities of man that vouch for their validity and integrity. What are the sources of drive and the character of the energy that breathe life into man? What are the characteristics and personal techniques of intellect and emotion that further man's aims, and how are they structured and organized? What, in more definitive terms than Bentham suggests, are the sources of man's perceptions and how, in specific manner, do they influence his behavior? It is by the lights of his address to these questions that one could judge whether Bentham's psychological man is anything more than a gratuitous set of ideas, based on the merest speculation and perhaps attended to some degree by common sense. Clearly, though, an injustice may rest in this latter view insofar as Bentham is criticized for not having anticipated the questions of the twentieth century psychology. And then, too, his psychological system may have been only as completely presented as his theories of legislation required. The remainder he may have too casually assumed to be a matter of common experience and understanding or of incidental importance.

Jurisprudential penetration into psychology has been bold and imaginative on the whole. In fact, one may say of it that it has been venturesome, a judgment scaled on the standard of the professional psychologist. The jurisprudential offerings, adjusted to their time, appear to have sensed some of the major intellectual dispositions regarding human behavior as they have been reflected in the work of major psychological theorists. In the amplification and addition, however, there are, commonly, impressive evidences of improvisation, drawn by the orbit of jurisprudence and characterized only in terms of its basic interests. There is also a palpable lack of significant detail, a lack of wherewithal to probe the psychological theory and develop or extend a process of insight and validation.

It is, of course, true that the psychologist's reservations may be turned on the psychologist. One may ask what right of presumption attaches to the psychologist's theories. In fact, seeming to be cognizant of a dearth of solid articulated information about psychological behavior, one might colorably suggest that our "basic instincts" regarding behavior are as apt as any criterion of insight and accuracy, and one may ask whether, in point of theory, Aristotle has been substantially superseded or improved upon by the psychologist.

Drawn into issue are matters of proof and matters of faith. The psychologist's ability to describe, manipulate and predict behavior in the light of his theories, though acknowledged as fallible, has been extended beyond doubt. There is generally less certainty about the 
jurisprudents' theories of behavior, even as to the purely psychological aspects. "Basic instinct" seems an altogether naive term of reference, or else it is sophisticated beyond understanding. And it may be said of Aristotle that he never pursued the questions that are consensually established as of greatest importance today in understanding and predicting behavior, those relating to it as a process.

The direction of inquiry is clearly more proper and of greater promise when it searches the basic proposition that law is best comprehended if it is perceived in terms of the psychology of the individual. This reasonably seems an appropriate reductio ultimum for a wide range of social behavior and social organization, including that relating to law. It seems comfortably certain that a total failure to observe and to consider this proposition renders any jurisprudential theory susceptible of being unrepresentative of life, incomplete and possibly erroneous.

One may add, gratuitously, that reasonably valid and adequate psychological theories of behavior are not enough. The coordination of the theory with propositions relating to law in its different guises, in a systematic framework, is another focus of crucial examination that is likely to be of more engrossing interest to students of law and jurisprudence. And then, too, a comparison of the probity of jurisprudential systems, having in mind here the psychologically oriented systems particularly, also comes into being as a natural manifestation of the native interests of theoretically-oriented students of law. The undertaking of a psychological theory of jurisprudence, and even the critical study of such alone, is something well beyond the scope here given to the problem.

\section{Psychologists' Theories Regarding LAw}

A bit of counterpoint to what has already been presented is the consideration of psychologists' theories relating to law. Mainly, psychologists do not contemplate law as an integral element in behavior theory, and it scarcely receives mention. Legal scholars given to large measures of grace might point to the great diffusion in concepts of law as the explanation. A grudging view, and probably the more accurate one, is that psychologists' theories have not advanced to the point where they are even ready to systematically differentiate the psychological effects of particular social institutions and processes, including law, on behavior, nor are they well prepared to develop the converse relationship.

In the theories of Freud, for example, law, however conceived, is only remotely an influence on behavior. It is predominantly the 
agency of conscience, and its more primitive forebearer, the superego, that structures the individual's cognition and response to law and morality. ${ }^{144}$ Conscience evolves out of a host of experiences with authority of which the considerably largest number and the most influential are fused through the identity and behavior of parents. Law is part of this experiential mass, largely undifferentiated in its properties, that is filtered down to the individual. The individual comes to know it and to respond to it almost instinctively, as a representation of the kind of authority manifest in the attitudes and actions of more familiar and more complete parental figures.

This process of "knowing" the law is substantially consummated and, short of drastic and complicated re-education, is largely irretrievable after the first few years of life.

Given such theory, the seemingly slight and incidental psychological significance attributable to law is not remarkable. Formal law in any sense is hardly within the purview of most children. The facilities for abstraction and bases of experience are lacking, except through others.

Somewhat more relenting is the psychological view of law postulated by the English psychiatrist, Ranyard West. ${ }^{145}$ Dr. West appears to stand squarely within psychoanalytic traditions in psychology, with its emphasis on the importance of instinctual elements and on "unconscious" processes in molding behavior. West's theoretical position is, however, an original deviation from Freud, at least as to the character of man's instincts and possibly as to their mode of operation.

Dr. West suggests that there are two "primary" instincts in man, the social instinct and the aggressive instinct. ${ }^{146}$ The social instinct serves the "need of others" while the aggressive instinct serves the "equally fundamental need" of man "to assert himself." 147 The two forces are in constant competition, though the social instinct generally prevails. In law, society provides an instrument to better insure that such will be the outcome. "The prime operative duty of law is the control of human aggressiveness." ${ }^{148}$ It is, in its psychological function, a reinforcing agency to thwart and discourage "the potential criminal in every man." 149

Law is simultaneously a suppressive agency, encouraging and supporting stability in man's relationship with his social environment. It is the latter emphasis that represents the view of law taken by a more

144. See notes 19,22 supra and accompanying text.

145. West, CoNSCTENCE ANd SOCTETY (1945).

146. See id. at 152 .

147. Ibid.

148. Id. at 165 .

149. Ibid. 
orthodox Freudian than Dr. West-Dr. Franz Alexander. Dr. Alexander, writing in collaboration with Judge Hugo Staub, ${ }^{150}$ suggests that a prime psychological function of law is to maintain and support the individual's sense of justice, "an inner psychic regulator, which automatically guarantees certain self-imposed restrictions in the interest of the community." 151 The sense of justice is a psychic equilibrator. By it, the individual renounces socially destructive drives with the implicit understanding or expectation that others will do likewise. The failure of adherence on the part of any individual is to be attended by society, and therein enters law. Any failure or inequity of the law in the redress of the balance in each individual's relationship to society results in a disturbance of every individual's sense of justice, and in disappointment and irritation with the law. It is, then, the importance of law to see that "the common sense of justice remains uninjured." 152 "When the public shows undisturbed confidence in the legal institutions and their official representatives, then we may say that the common sense of justice is in harmony with the demands of the powers that be."153 Failing this acquittal of law's function, then "the continuation of law and order becomes possible only through the increase of the external power of the law." 154

In Alexander's view, law is particularly recognized only as a supportive and protective agency for antecedent psychological processes, and it is destructive of these processes if it is not functioning with proper subtlety and effect. It would appear that the psychoanalytically oriented doctors, West and Alexander, are in agreement that law is a force of some instrumental psychic consequence to all individuals in society, and must be considered for its psychological meaning to the individual. But, for Dr. Alexander, law appears as an external influence on psychic processes that seem to take on their essential character elsewhere or in other terms. For Dr. West, law seems somewhat more of a fixed determinant in the psychological growth and, particularly, the behavior of the individual.

The preeminent learning theorist, Professor B. F. Skinner, also views law as a constant. He deals with it as a rule whose substance consists of some specified behavior attended by some proposed consequence to the individual who engages in such behavior. ${ }^{155}$ "A law 1956).

150. Alexander \& Staub, The Crminal, the Judge and the Public (rev. ed.

151. Id. at 13 .

152. Ibid.

153. Ibid.

154. Ibid.

155. See Skinner, Science and Human Behavior 138-39 (1953). 
is a rule of conduct in the sense that it specifies the consequences of certain actions which in turn 'rule' behavior." 156 Professor Skinner thus takes the position, consonant with reinforcement theories of learning, ${ }^{157}$ that law influences individual behavior by producing effects upon him, usually in the nature of punishment, when he violates rules that have the formal sanction of a government agency. Behavior may not be, and probably is not, originally conditioned by the controlling practices and contingencies set forth for behavior by governmental agencies. The actual conditioning is left to others-parents, friends, other agencies - most certainly so as to the minor contingencies of behavior that set the pattern for ethical conduct. To the extent that governmental law is a controlling agency in behavior it acts as a reinforcer of patterns of conduct already developed through other instrumentalities. ${ }^{158}$ Phrasing its effect differently, a law, by creating unpleasant effects, for others as well as for the individual himself, reduces the probability that any individual will engage in a particular behavior. The individual receives "aversive stimulation" that influences his behavior response.

Professor Skinner's view of law is familiar, though perhaps cast in a newer language and a more disciplined descriptive system. To be entirely fair to Skinner, however, it must be recognized that his references to law are only allusive and intend no definition or scope as to its full psychological quality. His concern is to show the potentiality of a learning theory approach to explain a large range of behavior.

Alexander, Skinner, and perhaps to some extent West afford only brief reflections on law in passing to some other matter that is more certainly in the orbit of their attention. Usually, this matter is the causal explanation of psychological behavior, and the consideration of social problems relating to this behavior. There is no fuller contemplation of the law in terms of psychological process. Partly, it is because law, in their minds at least, does not enter that much into the discussion. Partly, too, there is the connected explanation that law is known or contemplated only colloquially or, at best, very narrowly. There is a ring of substantial unfamiliarity in discourse about it. Yet, among the more theoretically inclined, these gentlemen appear to have ventured further into the matter than any other contemporary psychologists, judged by Anglo-Saxon writings.

There is a clear challenge to be recognized at this point, a challenge to make more capital of the possible theoretical connections

156. Id. at 339.

157. See authorities cited notes 34,35 supra.

158. SKINNER, op. cit. supra note 155, at 339 . 
between law and psychology. A polished theory is perhaps beyond present reach, but there may be timely gain from hypotheses, hypotheses whose credibility in the minds of others now rest only in their apparent truth as given by surmise and by "feeling."

Following are just such hypotheses about the psychological meanings and influences of law in individual and, to a lesser extent, social behavior. Their emphasis is upon some reciprocal subconscious processes and effects between the structure and operation of authority in law and the behavior of the individual. The nodal premise is that individuals shape and share social experience because of a drive emanating out of and responding to a natural condition in social life.

\section{Psychological Dependency and the Law}

Man's struggle for self-determination is a constant reminder that dependency is his natural state. He is dependent on his culture, on his fellow men and, with all of that, on the vicissitudes of blind nature. The master psychologist, Freud, ${ }^{159}$ viewed dependency as the earliest state of human life. If it persisted well into life it was a pathological state. Dependency was a condition identified within the scope of close family relationships and, in the normal state of affairs, one obviously outgrew one's dependency upon one's mother.

But, in a larger pantoscope, one does not "outgrow" the support of culture and human relations. In fact, the longer one endures social living the more one becomes dependent on its contacts and its instrumentalities. As to man's culture, at least, Freud does acknowledge that man is "destined to remain a child forever." 160

However, the story behind psychological theories of adaptation is that man has been anything but entirely submissive to his natural state. Prodded by his native talent, particularly his genius for imagination and problem-solving and, with these, taking hold of the frustrations and challenges presented in his environment, man has dissociated himself somewhat from raw nature. $\mathrm{He}$ is rebellious, ingenious, creative, resourceful and otherwise equipped with drive and intelligence to counter and change his natural state. His is the constant struggle of independence versus dependence, of adjustment and fulfillment, of security and freedom. He is, basically, in a state of perpetual ambivalence that is more or less stabilized in notable behavior patterns.

159. Freud said comparatively little about man's dependency as a matter of support in relation to his environment. His occasional references to the subject may be found in THE FuTURE OF AN ILLUSion 28-42 (Robson-Scott trans1. 1928), and cf. ThE Problen of ANXIETy 108-09, 149-51 passinn (Bunker transl. 1936).

160. Freud, The Future of an Illusion 42 (Robson-Scott transl. 1928). 
In the concatenation of drives and forces, law is not exempt. Law nurtures and ministers to our dependency. We rely on its authority and its strength to punish the bad, right wrongs, protect us against evil and give us our fair share of things. With more notable pith, Jerome Frank states that man "unconsciously has tried to find in the law a substitute for those attributes of firmness, sureness, certainty and infallibility ascribed in childhood to the father." 161

But, being palpable theorists in our daily lives, we also resent law to some extent. We resent its monopoly of strength, its uncompromising demands for adaptation and order, its blundering execution of purpose, its insensate morality. We resent the way in which it frustrates our drives and sometimes our personal judgments even as it binds us to the rest of humanity in doing so. It is too much the tool of adjustment and the frustrating agent of what West has termed the "self-assertive instinct." 162

Our basic attitude toward law, before the refinements induced by the Freudian devices of conscious and unconscious suppression, and rationalization, is one of ambivalence. We want it, need it-and dislike it. Our primitive dispositions are revealed in our attitude toward the criminal offender. Much has been said of our animus toward this offender and our desire to see him punished. ${ }^{103}$ But not enough has been said of the vicarious satisfaction we feel and sometimes express when the criminal offender "beats" the law. It may be, as Alexander suggests, that we all have "genuine criminal instinctual drives" 104 which we share with the criminal. This choleric interpretation may be adjusted to indicate that our feelings express appreciation for the independence asserted by the offender, however poor his social judgment may have been.

Our basically uncertain attitude toward the law, one of many ambivalences we hold, contributes to great personal discomfort. Psychic economies demand some better resolutions than continuing overt conflict, and so we adopt distinctive patterns of behavior in relation to the law.

161. Frank, Law and the Modern Mind 21 (1949).

162. See text at p. 500 siupra.

163. See, e.g., Reiwald, Society and Its Crminals 246-82 (1950); AleXander \& Staub, op. cit. supra note 150, at 215-23; Weinofen, The Urge To Punish 138-41 (1956); Zilboorg, The Psychology of tHe Criminal ACT and Punishment 75-95 (1954). One is here reminded of Sir James Stephen's famous dictum, "[T] tion of criminal justice ... stand[s] to the one set of passions [deliberate anger and righteous disapprobation $]$ in the same relation in which marriage stands to the other [sexual passion]." 2 Stephen, A History of the Criminal Law of England 82 (1883).

164. AteXANDER \& STAUB, op. cit supra note 150 , at 30 . 
In their ultimate adjustments most people accept their dependency upon the law and recognize it as one of the devices that regulate the dangers and uncertainties in social reality with which they cannot cope by themselves. Law is mostly ultimate and beyond reach, and dependency is full and complete. Dr. Kardiner describes this process of stabilizing dependency feelings in the following terms:

"[Dependency] is a basic ego attitude necessary for survival, in response to an anxiety resulting from a feeling of helplessness, or to a feeling of limited resources, strength or ability. The attitude is one of soliciting support, help, or protection. The subject will . . . delegate to the object of dependency great powers, will attribute to him abilities to do things which the subject cannot do for himself." 165

The basic struggle, independence versus dependency, passes to the unconscious in this area of experience and, if it persists, will be sustained on some other social front. Dependency on the law is the prevailing attitude. Consciousness of conflict about this attitude is likely to occur mostly when there is an acute exposure to or awareness of the operation of law.

Occasionally, the personality committed to dependency upon the law will surreptitiously transgress the law, traffic laws for example, as if to deny complete dependency and the insuperability of the law. In fact, the proof is weakly chosen and unconvincing, since the risks in transgression and punishment are slight. The action is mostly symbolic. The transgressor would assert a tendency to deny complete dependency, but not to the point of seriously challenging law as a source of support, and injuring himself in the process.

There are, in fact, rebels dedicated in their opposition to law. These are the persons, denominated criminal for the most part, who have not come to terms with their basic conflict. Opposition to law symbolizes their struggle for independence and theirs is a constant effort to deny their dependency. Dependency is, however, their basic condition and, notwithstanding the opposition, their basic expectation. Their actions belie their professed attitudes, as they provoke the law to make decisions and arrangements for them. Mostly, they cannot overcome the law and do not expect to. Their criminal acts, the evidence of protest against their weakness, are the simultaneous admission of dependency. In the end, they have "no more pressing need than the one to find somebody to whom [they] can surrender." 166

165. Kardiner, The Individual and His Society 32 (1939).

166. Dostoevsky, The Brothers Karamazov (Garnett transl. 1955). 
Suppression and adaptation confirm a massive dependency upon the law. Aggression and opposition are not an effective denial. Dependency is the expected and the confirmed state of adjustment. It is only exploitation that pivots the balance wheel so as to evidence man's success, from time to time, in establishing some psychological autonomy for himself.

Exploitation is the betrayal of man's wishes to conform reality to some personal image of a superior state of existence. Depending upon his vanity, he may contemplate this state only for himself or for as much as all humanity. The boldness of his plan marks the degree and the kind of balance he would achieve between his strivings for independence and his natural state of dependency. The extent of his success identifies the degree of independence he has in fact achieved.

The exploitation of law is generally a well-guarded effort, protected and often disguised in terms of conformity to some set of social practices that, in themselves, have a dutiful attitude toward the law. The exploiter conforms to business or professional practices, or political proprieties, or scholarly methods, as he seeks to gain particular advantage of and even modify the law. A general dependency on some strength and authority outside of himself is acknowledged, but it also serves as a base for asserting some personal independence in regard to the law.

The successful exploiter establishes a base of his dependency upon his environment and uses this to achieve some relatively small degree of independence from it. Acknowledging dependency as a natural state, he is, relatively speaking, psychologically independent. The unsuccessful exploiter misinterprets the foundations of his independence and pushes himself out on a limb without support. His strivings for independence fail to calculate adequately his need for support and for disguise. His frustration is the more complete as his boldness is his undoing and he is frequently coerced into a state of complete psychological dependency.

The temper of those who work closely with the law is cast in the same mold as the rest of humanity on the matter of dependency. In fact, those close to the law tend to exaggerate, and even to caricature, the character of human adjustments to the problem.

The largest majority of law-workers characteristically assume and accept a role of complete dependency in relation to the law. Law, in the subconscious, represents support and sustenance for strong dependency. The law-worker is the servant of law. He faithfully supports and upholds it, executes it and asserts its predominance and authority, and simultaneously receives gratification in doing so. $\mathrm{He}$ 
evidences a strong subconscious, and sometimes conscious, resistance to tampering with it. To safeguard his attitude and acceptance of dependency in relation to the law, the law-worker may create and support an aura and mystique about it, bordering on the invocation of magic. The mystique disguises and does away with uncertainties about the law and resentment against it. To be sure, the law-worker does not fool himself completely by what he is doing but he would rather have the ironic touch that law thus gives reality than discard the veil that nurtures and protects his dependency.

In a sense, everybody is dependent upon some larger identification, outside of personal life, to cope with physical and social realities. Education, the more so particular kinds of education, and social and occupational identifications place a person in a more secure relationship to larger social realities and enable him to cope with them. Those whose identifications are with law simply select a more certain and more definite means for continuing and satisfying dependency, and coping with social reality.

But among law-workers there are also those who express opposition to the law as an element of their struggle over dependency. And these in turn are at least superficially close to others who exploit the law in a truer effort to gain independence.

There are among law-workers some who actively seek the shelter and nurture law provides their psychological being. The acknowledgment of dependency, however, is a troubling denial of personal strength and autonomy. Under cover of law, they seek to deny their dependency through a bruising assertion of authority. The larger and the more entrenched the dependency, the firmer may be their protest. Theirs is none of the substance of independence; they assert only resistance in the form of a demonstration of personal power that the law itself gives. Their adjustment has many of the marks of the "identification with the aggressor" so acutely described by Anna Freud ${ }^{167}$ within a more clearly Freudian framework of behavior. In their most extreme virulence they are "psychopaths on the side of the law."

The exploiters among the law-workers essentially accept their dependence upon the law. Theirs is an effort to make law a nobler or more responsive device. Their effort is a monument to personal talent and, of more particular psychological moment, evidence of substantial strength and relative independence. Their contemplation of balance or adjustment in the qualities and uses of the law is the social manifestation of a psychological process involving the adjustment of

167. A. Freud, The Ego and the Mechanisms of Defence 117-31 (Baines transi. 1946). 
independence versus dependency needs. They draw mixed and sometimes conflicting reactions of awe and approval, and fear, opposition and resentment, as they tamper with basic views, feelings and adjustments in the essential psychological struggle that is keen to law-workers and common to all. In the end, they may verge on parasitism, a familiar accusation against less principled lawyers, ineffectual scholars and incautious judges. Or, if they are the likes of a Justice Holmes ${ }^{168}$ and, more particularly, a Justice Cardozo ${ }^{169}$ in the skill of their efforts and the sweep of their success, they will be anointed with a nobility and authority almost as great as that of law itself. They become the symbols of genius, of strength and justice and, at rock bottom, of psychological independence.

The psychological archetypes represent the dominant strains in human adjustment and characterize essential dispositions as regard some important element in behavior, e.g., dependence versus independence. They exist in their pure-bred state but they are also subject to hybridism. In fact, for any individual they may be in particular stages of hybridization or change-over ranging in effects from complete conflict and uncertainty to exaggeration or confusion. The possibility of characterology is multiplied no end but it is recognition of the essential elements and dispositions that are important, for these are the working materials of adjustment and progress. They are human mortar, so far as the law is concerned. In biological terms, they provide its tissue culture.

\section{Law and the Sense of Justice}

The sense of justice, as Professor Edmond Cahn points out, is static and merely contemplative. ${ }^{170}$ It is really the sense of injustice that moves us. To Professor Cahn, the sense of injustice acts as a social balance wheel for the law. It mediates for the law and guides it. In our psychological framework, the sense of injustice is the small but penetrating voice that signals psychological distress, akin to the sense of pain that Jhering describes in The Struggle for Law. ${ }^{171}$ It signals threat and frustration to the balance and adjustment achieved in the basic struggle relating to dependency. It is the outcry when law acts to smother us too completely and, on the other hand, it is the anguish when dependency upon the law is brusquely challenged or denied.

168. Holmes, The Common LAW (1881) is prime evidence of an exploitative mind in relation to law.

169. Perhaps the finest exploitative effort in connection with law is to be found in the acutely developed ideas and views Cardozo presents in The Paradoxes of Legal Sctence (1930) and in The Nature of the Judicial Process (1922).

170. Cahn, The Sense of INJUSTTCE 13 (1949).

171. See id. at 41 . 
The excesses of the demands of law bring to a state of consciousness acute feelings of restriction and frustration resulting from the complete power and dominance of this social agency. Law can support the human personality, and its support may be accepted and even solicited. But, if its effect is recognized as stifling, it breeds anguish, discontent and opposition.

At the other extreme, for law to permit a degree of opposition that challenges its supremacy, or a degree of independence that denies essential dependency upon it, is equally cause for distress. Borrowing from the more sanguine interpretive framework of Alexander, injustice "transforms the chronic yet static state of embitterment into an acute dynamic state of rebellion." 172 It must retain its nurturant and regulative character with great consistency.

The sense of injustice is an ultimate human resource for regulating and safeguarding stable psychological adjustments to social reality. It does so by maintaining a symbolic relationship with the law.

The sense of injustice is keenest in those whose exploitation of the law reveals a greater (conscious or subconscious) sensitivity to balancing and adjusting basic psychological dispositions. In them it becomes a driving mechanism to adjust the relationship between the state of dependency of the human being and the scope and power of the law. If attestation were to rest in one example, Jerome Frank would be the obvious case. ${ }^{173}$

The sense of injustice is the least developed where justice acts merely as the alter ego of law and total dependency is the heavily predominating state of life. Injustice is synonymous with a failure to give authority its due. Extrapolating from the psychologist Piaget's findings on the earliest developmental stage of the sense of justice (and injustice) in the child, ${ }^{174}$ justice is felt when there is confirmation of a state of complete dependency on external authority. Anything less than a complete acknowledgment and responsiveness to authority is a provocation of the sense of justice.

172. Alexander \& STaub, op. cit. supra note 150 , at 4.

173. Frank makes a firm case for this statement by his two principal writings, LAW AND THE MODERN Mind (1930) and Courts on TrTal (1949).

174. See Piaget, The Moral Judgment of the Child 314 (1948). Piaget distinguishes three stages, or phases, in the development of a sense of justice. In the earliest stage, there is "non-differentiation of notions of just and unjust from those of duty and disobedience: whatever conforms to the dictates of adult authority is just." Ibid. In the second stage, there is "progressive development of autonomy and the priority of equality over authority. ... [T] he only punishments accepted as really legitimate are those based upon reciprocity." Id. at 315 . The third stage is "characterized by a feeling of equity, which is nothing but the development of equalitarianism in the direction of relativity. Instead of looking for equality in identity the child no longer thinks of the equal rights of individuals except in relation to the particular situation of each." Id. at 316. 


\section{Litigation}

From the titillation of self-love, many legal theorists have tended to view litigation as a mutually beneficial reciprocity arrangement between law and humanity. Litigation is law's window to humanity. Because of the window humanity is better provided for by the law and happier about it. It is the dark-sided nature of litigation that is avoided, deflecting from a view of it as a mixed blessing at best.

Couched in terms of pragmatic psychological meanings, litigation is evidence of a limitation in human development or of regression. The litigant gives evidence of lacking the necessary personal strength and resources to cope with reality, even after the structure of law, particularly its rules, has imparted some means of support. As Goitein suggests, the litigant suffers feelings of "depreciation and deprivation." 175 His is a state of weakness and regression. Dependence upon the law becomes acute and inevitable.

The litigant enters into a therapeutic relationship with the law. But he seeks only a closer identification with it, a firmer dependency so that he can borrow its strength. The law's response is to encourage the dependency of litigants. It offers more concerted support to some and restricts the strivings toward fuller independence of others. The therapy law offers in litigation is generally supportive or repressive. It produces a mostly unconscious encouragement for a state of fuller dependence and intensifies the natural, conservative disposition of the largest segment of human beings. For those who continue an active struggle for growth beyond the state of dependence, the operation of law in litigation tends to intensify their conflict. It is only in heroic instances that exploiters of the law succeed in turning litigation to the advantage of an independent turn of mind. Their tactic is to camouflage their operations so that they might be interpreted as in support of and reliance upon the existing law, giving no evidence that the demands of law for dependency are not being met.

Generally, it is the prosecuting litigant who seeks to invoke the greater power of the law and dependence upon it. Yet, curiously, the litigant is in the anomalous position of electing not to do so should he so choose. He holds the means of protecting and favoring any tendency toward a stronger personal independence. In the case of private prosecutors this is mostly a figurative choice, since they are generally reduced to a state of weakness where marked dependency is almost necessary. The public prosecutor, however, and, to a lesser extent, the trial decision-makers, protected in their identification with law, have a dis-

175. Gortenn, Primitive Ordeal and Modern Law 254, 267-69 (1923). 
cretion to decide the extent to which dependency will be enforced or independence will be encouraged. Mostly, they accentuate the disposition of the mass of humanity in their own beings. They close the gap on freer action and assert more repressive claims, less in deliberate contemplation of theoretical considerations and by reason of the evaluation of consequences than in subconscious response to acute psychological dispositions seeking greater comfort and safety.

Litigation is concerned more with the most careful preservation of the power of law and the encouragement of dependency than with the prospects for litigating parties. The energy devoted to the techniques of operation demonstrates its self-concern. It is encouraged in this attitude by the nature of its immediate clients. Regressed and weak, they expect and tolerate the more primitive force of law evidenced in litigation. Bare knuckles and sheer force, with poorly disguised amenities, under the shadow of great power and protection, are the mark of an overwhelming authority displaying its strength to emphasize the weakness and dependency of those about it. It is a brutal form of reassurance as to the position of the parties, law and litigant, from which both the law and the particular litigant derive a measure of conscious or subconscious satisfaction.

\section{Administrative Process}

The steady drift toward administrative processes is evidence of a substantial desire to tone down and even to dilute the devastating power and the oppressive effects of judicial law in operation. Administrative processes veil the power and the demand of naked authority by giving it the appearance of being more diffuse and less concentrated. Their intended disposition is to encourage greater self-regulation in respondents and the arbitration of differences rather than the imposition of solutions. They are, in theory, a sensitive response to the growth potentials and independence strivings that exist in states ranging from dormancy to volatility in the mass of humanity. Administrative processes evidence the benevolent paternalism of law encouraging the growth and greater independence of humanity, offering not only support but also greater self-direction for the largest number.

The subconscious purpose of administrative process is something less than satisfied. For the larger number of persons who seek only total dependency upon the law, the freedom administrative process offers is in the nature of burden and frustration. They seek "escape from freedom" in the pattern suggested by Horney, ${ }^{176}$ compensating for

176. See text at p. 475 supra and Horney, The Neurotic Personality of Our Tne (1937). 
inadequacies and frustration by seeking out mantles of power, prestige and possession. They do not grasp and respond to the potentials and values of administrative procedure. Since the power of law is veiled and even diluted in the character of administrative process, those who only oppose the law in repetitive compulsion find it easier and safer to do so where it is administrative law that is concerned. And, finally, the deconcentration of law in administrative processes seems to encourage mostly parasitic exploitation. The exploiter who seeks personal advantage is more easily satisfied than the exploiter who eyes the general welfare.

The psychological theory of administrative processes is in the midst of a crossfire when put to a practical test. Erosion occurs because the administrator-representatives of the law are able to exercise their own native dispositions with blighting effect. In the main, they are dependent personalities who stay close to the law for the support that identification with it begets. The intended fluidity of administrative processes dissolves in their hands because they are accustomed to expect and receive the benefit of the rigid and rigorous framework of the law. Their response to the design of administrative procedures is, on the one hand, to create and assert, in the name of the law, a rigid pattern of operations and expectations, and inflexible standards of decision. Subconsciously, they steel the pliant framework of administrative process so that it cannot be discerned as different from the traditional, primitive courtroom framework of operation.

On the other hand, when the agent of the administrative law does make the effort to respond to the enlightened purpose of administrative process, his entrenched dependency renders him without any developed psychological talent or experience for the task. His lack of such skill and discipline increases the attraction and need of sheer power. $\mathrm{He}$ is himself inclined to be demanding and impatient, uncritical, insensitive and arbitrary. He is little Napoleon with epaulets and no pants.

Administrative process is an experiment with "human nature." In the sheer scope and the nobility of its effort, it has reason to expect more patience and tolerance, and more careful study, than it has received in some quarters.

\section{Legislation}

Legislation is memorialized in time as a process wherein man can dramatize the potency of his strivings for independence. It is a glamorous instrument to be manipulated by man to the end of success against and in relation to his social environment. However, the 
psychological reality is that legislation is split in its personality. It is simultaneously an instrument of law, for law, and against law.

Man's use of legislation evinces his basic dispositions and conflicts. As an enterprise, it is attractive to some of man's segment that is keen on self-assertion and on some degree of domination over a total state of dependency. On the other hand, it appeals to others primarily as a vehicle for insulating existing order, or a higher degree of dependency on the status and character of the social environment. It is this basic conflict between and within men that compromises the total effect of legislation in any one direction, short of a cataclysm that nudges it off the fence and onto one side. Legislation is, on this account, chaotic and conflict-dominated. Its great moments are reserved more to eloquence than to accomplishment, though there is sometimes a causal connection between the two. Typically, legislation may begin on a moment of high anticipation, with the exploitative man feeling great powers and urgencies to contravene the general state of dependency in some particular. The espousal creates anguish to the subconscious determination of others to maintain a sedate state of support on existing reality. Only near miraculous persuasion and loaded threats of coercion can, from time to time, preserve the identity of legislation as the original mark of man on and over his environment. More characteristically, the legislative process follows a course of expediency and may thunder to a climax by exercising its authority over the institutions dependent upon it, through generally conservative control of its means of support and by coercively reinforcing an attitude of dependency upon this great power-bearing element of law.

Legislation acutely mirrors man's conflicts more than, at least more often than, it does his particular strivings in either direction of independence or dependency. Because it is so impeded, the stronger instances of direction in man's connection with law are to be found either in litigation or administrative processes. Legislation is man's publicized self-view, but litigation and administrative process may be more likely to determine man's standing in life. In truth, of course, it must be recognized that there is a multiple relationship of psychological give and take between the processes of law, and there is some diffusion in role and appearance. However, each would appear to preserve some cardinal characteristics and a discrete psychological identity. 